\title{
Viruria in Dogs after Injection of Coxsackie B-1 Virus into a Renal Artery*
}

\author{
Irwin Schultz and C. Larkin Flanagan $\dagger$ \\ (From the Departments of Microbiology and Medicine, Northwestern University Medical School, \\ Chicago, Ill.)
}

Viruria has been demonstrated in many human and animal viral infections $(1,2)$. Preliminary studies in mice and rats by Schultz and Neva (3) established that virus passes from blood to urine within 30 minutes after intravenous injection under the conditions of their experiments. This viruria was referred to as "immediate viruria" and was considered to be distinct from the viruria that occurs during acute infections. In the present study, dogs were used in experiments that were technically too difficult to be carried out in smaller laboratory animals. Renal physiological and virological techniques were combined to study the mechanisms of virus clearance from the blood by the kidney and to establish the locus in the nephron where virus gains entry into the urine. Previous studies of a similar nature include those of Keller and Zatzman (4), who injected Bacillus megatherium phage and studied its renal excretion and distribution in the liver and spleen of dogs. Petrov (5) used injection of bacteriophage of Escherichia coli in dogs to establish clearance values for these virus particles. Although Schultz and Neva (3) were unable to determine the renal contribution to viruria in rats, they observed that the rat bladder is permeable to small numbers of virus particles.

Our present studies demonstrate that Coxsackie B-1 virus (a small enterovirus) can pass rapidly

* Submitted for publication May 3, 1965; accepted August 19, 1965.

This investigation was supported by U. S. Public Health Service research grants H7057 and H5860 from the National Heart Institute, and AI 4760 from the National Institute of Allergy and Infectious Diseases.

Presented in part before the Fifty-fifth Annual Meeting of the American Society for Clinical Investigation, Atlantic City, N. J., April 1963, and abstracted in J. clin. Invest. 1963, 42, 931.

† Address requests for reprints to Dr. C. Larkin Flanagan, Northwestern University Medical School, Ward Memorial Bldg., 303 E. Chicago Ave., Chicago 11, Ill. from blood to the urine after injection into a renal artery. Similar findings were noted after injection of virus into the aorta or into a peripheral vein. Moreover, with the stop-flow technique (6), localization of the point of initial viruria was possible. The site appears to be in a distal portion of the nephron, perhaps in the distal tubule.

\section{Methods}

\section{Experimental design}

Male mongrel dogs weighing at least $17 \mathrm{~kg}$ were anesthetized with 10 to $15 \mathrm{mg}$ per $\mathrm{kg}$ of sodium pentothal injected intravenously. A no. 18 Rochester catheter (2 inches in length) was inserted into the right renal artery by a modification of the technique of Pullman, Lavender, Aho, and Rasmussen (7). The catheter within the right renal artery was attached to a constant infusion pump, and a $0.9 \% \mathrm{NaCl}$ solution containing $0.01 \mathrm{mg}$ per $\mathrm{ml}$ heparin sodium was infused at $1.23 \mathrm{ml}$ per minute. Through an abdominal incision, no. 240 polyethylene catheters (i.d., 0.066 inch; o.d., 0.095 inch) were placed in the upper portions of both ureters. After 60- to 90minute intervals, urine specimens were examined for microscopic hematuria (more than a rare erythrocyte per high power field in a centrifuged specimen) before control periods were collected. The experiments to be reported were selected from an original total of 23 dogs. Reasons for discarding the experimental results from the other animals included gross hematuria (four animals), microscopic hematuria (two animals), questionable renal arterial catheter placement (two animals), and postmortem evidence of severe diffuse renal disease without hematuria (one animal). An infusion of $15 \%$ mannitol into a cephalic vein usually was given to insure good urine flow rates; in some of the stop-flow experiments this infusion rate was as high as $14 \mathrm{ml}$ per minute.

The virus inoculum described below was first introduced into the tubing leading to the renal artery and then infused by increasing flow through the pump to $9 \mathrm{ml}$ per minute. With heparin as anticoagulant, blood samples were drawn into sterile syringes from the right femoral artery. Two types of experiments were performed:a) those in which urine was allowed to flow freely from the ureteral catheters, and $b$ ) those in which the stop-flow technique was used. 
During the free-flow experiments, roughly equal urine flow was established on the two sides (Table I). After control periods, virus inoculum, containing approximately $1 \mu \mathrm{c}$ Iodohippurate- ${ }^{131} \mathrm{I}$ (Hippuran- $\left.{ }^{131} \mathrm{I}\right)^{1}$ was infused. Urine collections were made directly into the sterile glassware to be employed in the quantitation of virus.

In the stop-flow experiments, $15 \%$ mannitol was infused until the urine flow rates were about $5 \mathrm{ml}$ per minute from each side. Control clearance periods were collected. Both ureteral catheters were then clamped for 6 to 8 minutes. During the final 2 minutes of the clamping, virus inoculum containing Hippuran- ${ }^{131} \mathrm{I}$ as a proximal tubular marker was injected into the renal artery. After release, the rapid flow of urine was collected into previously unused $2-\mathrm{ml}$ glass vials placed in a metal rack on a track. Each sample contained approximately $1 \mathrm{ml}$ of urine. Twenty to 30 vials were filled from each ureter within the collection period of 3 minutes. Immediately after the stop-flow collections, conventional renal clearance period collections were made again. In four experiments, sodium ferrocyanide, $1 \mathrm{~g}$ in $10 \mathrm{ml}$ of normal saline, was injected into a cephalic vein at the same time that virus was being infused into the renal artery. This substance marked "glomerular" samples of the stop-flow collections (8).

All animals were sacrificed at the termination of the experiment. Postmortem examinations, including en bloc removal of the aorta, renal arteries, and both kidneys, were made to confirm the position of the renal arterial catheter and to observe the gross appearance of kidneys and ureters. Sections of kidney were fixed in formalin, stained with hematoxylin and eosin, and examined by light microscopy.

\section{Virus techniques}

Tissue culture. A derivative of the $\mathrm{Hep}-2$ cell line purified by single colony cloning was used throughout. ${ }^{2}$ The cells were maintained in continuous passage in 32ounce, flat prescription bottles as monolayer cultures and dispersed by trypsinization for passage or setting up tube or plaque bottles. Growth medium was modified Eagle's minimal essential medium in Hank's buffered saline solution containing nonessential amino acids ${ }^{3}$ and supplemented with $10 \%$ inactivated calf serum. Cultures were maintained after inoculation into a medium with $5 \%$ calf serum. Both growth and maintenance media contained penicillin $\mathrm{G}, 100 \mathrm{U}$ per $\mathrm{ml}$, and streptomycin, $100 \mu \mathrm{g}$ per $\mathrm{ml}$. The Hep cell line used for virus detection was known to be contaminated with pleuropneumonia-like organisms (PPLO), but subsequent parallel titrations in it and a line that was PPLO free gave identical results in both cell lines.

Virus. Coxsackie B-1 virus derived from the prototype Conn-5 strain of the American type culture collection

1 Abbott Laboratories, North Chicago, Ill.

2 The Hep-2 cells and virus were kindly provided by Dr. M. R. Rosbaum, Naval Medical Research Unit 4, Great Lakes, Ill.

${ }^{3}$ Microbiological Associates, Bethesda, Md. was received after three cycles of plaque purification in Hep-2 cells. A single large pool was prepared by high multiplicity infection of bottle cultures of Hep-2 cells that were incubated for 24 hours in buffered saline solution. The infected cells were frozen and thawed twice, and the cell debris was removed by centrifugation at $2,500 \mathrm{rpm}$ and $4^{\circ} \mathrm{C}$ for 15 minutes. The clarified virus suspension was dispensed into 3 -ounce bottles and stored at $-20^{\circ} \mathrm{C}$ until used. The virus titer of thawed samples remained at $10^{8} \operatorname{TCID}_{50}(50 \%$ tissue culture infective dose) per $\mathrm{ml}$. Thus, the virus inoculum $(8$ to $10 \mathrm{ml})$, diluted if necessary in buffered saline solution, contained in addition to Coxsackie $\mathrm{B}-1$ virus, the $\mathrm{Na}, \mathrm{K}$, and $\mathrm{Mg}$ salts of Hank's buffer, bicarbonate, penicillin, streptomycin, phenol red in a concentration of $0.4 \mathrm{~g}$ per $\mathrm{ml}$, and unidentified soluble components of the virus infected cells. It was shown to be free of bacterial contamination by testing 1-ml samples with thioglycollate broth, blood agar, PPLO agar, and Sabaroud's medium. Virus was reisolated from urine on three occasions and identified by a standard typing procedure with Coxsackie B-1 rabbit antiserum. ${ }^{4}$

Virus detection. 1) Tube method: Virus was detected in specimens of blood or urine by inoculating the cell cultures with 0.1 to $0.2 \mathrm{ml}$ of material in appropriate dilution in phosphate buffered saline, $\mathrm{pH}$ 7.2. All tubes were placed in a roller drum at $35^{\circ} \pm 1^{\circ} \mathrm{C}$ and read for cytopathic effects of virus on days 3 and 7 when medium was changed. All tubes were discarded at 10 days after final reading. Only complete specific destruction of the cell sheet was considered a positive result. The end point of titrations for the $\mathrm{TCID}_{50}$ was estimated by the ReedMuench method using 4 tubes per log dilution implying a SD of \pm 0.3 to $0.47 \log _{10}$ according to the empiric Pizzi formula (9). Tube cultures were particularly useful in detecting minute amounts of virus in urine.

2) Plaque method: In many experiments, the soft agar overlay method (10) for plaque titrations was also used to detect virus in parallel with tube titrations. Two-tenths $\mathrm{ml}$ of inoculum was absorbed to at least three plaque cultures in 3-ounce bottles for 1 hour before addition of the agar overlay. Plaque techniques were inadequate for detecting small amounts of virus and were not used in stop-flow experiments. All data will, therefore, be reported in terms of the $\mathrm{TCID}_{\mathrm{5} 0}$ of the tube titrations used in each experiment.

\section{Chemical and isotopic determinations}

Exogenous creatinine clearance was measured according to standard techniques (11). Plasma and urinary electrolytes were measured by flame photometry (12), and urinary ferrocyanide was measured by a modification of the Prussian blue method (13). A standard well counter with automatic sample changing and count recording equipment ${ }^{5}$ was used to count ${ }^{131} \mathrm{I}$. No correction for elemental ${ }^{131} \mathrm{I}$ [unbound to hippurate (14)] was made.

4 Obtained from the Communicable Disease Center, Atlanta, Ga.

5 Nuclear Chicago, Des Plaines, Ill. 


\section{Results}

Free-flow experiments. Preliminary experiments in which virus was injected intravenously or into the right renal artery revealed that viruria occurred regularly when the inoculum caused plasma levels greater than $10^{2} \mathrm{TCID}_{50}$ per $\mathrm{ml}$. When virus was infused over a 1-minute period, plasma levels plateaued at 1 to $1.5 \log _{10}$ below the estimated dilution of the inoculum in the total plasma volume. Thus, after injection of $10 \mathrm{ml}$ of $10^{8} \mathrm{TCID}_{50}$ of virus, plasma levels of $10^{4}$ to $10^{5}$ were observed at 3,10 , and 20 minutes after completion of the injection. These results were consistent with the observations of relatively slow clearance of enteroviruses from the blood of small animals reported by Schultz and Neva (3) and also by Mims (15).

The results of a representative free-flow experiment (dog 19) are shown in Figure 1. After injection of $10 \mathrm{ml}$ of virus suspension (containing $10^{8} \mathrm{TCID}_{50}$ per $\mathrm{ml}$ of Coxsackie B-1 virus) at a rate of $9 \mathrm{ml}$ per minute into the right renal artery, viruria was detected in urine samples collected 2 minutes after the beginning of injection. Viruria on both sides reached peak concentration in the 8-minute samples. A higher virus concentration was noted in the first specimen from the kidney that had been injected, compared to the uninjected side, but thereafter, the urinary concentration of virus was the same from both sides. The Hippuran- ${ }^{131}$ I dissolved in the virus inocu-

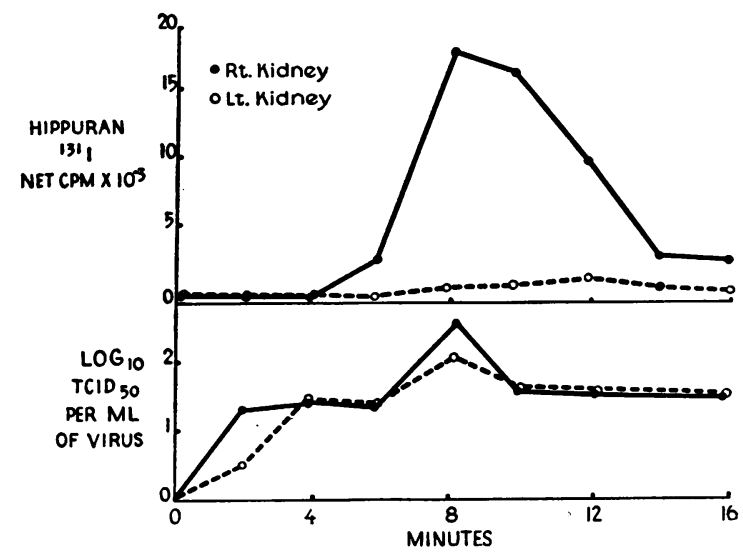

FIG. 1. A TYPICAL FREE-FLOW EXPERIMENT FOR THE STUDY OF VIRURIA IN THE DOG. Recovery from the urine of Hippuran- ${ }^{181} \mathrm{I}$ and Coxsackie B-1 virus injected into the right renal artery. $\mathrm{TCID}_{\mathrm{s}}=50 \%$ tissue culture infective dose.

lum was excreted almost entirely from the right kidney. The radioactivity appeared several minutes after viruria and simultaneously with the appearance of the phenol red also injected with virus.

The results of six free-flow experiments are outlined in Table I. Bilateral excretion of virus was the rule, indicating little, if any, advantage to the injected kidney. Virus was detected at the same time as or before the first appearance of Hippuran- ${ }^{131} \mathrm{I}$ in all cases. The wide range of urine flow rates (from $0.4 \mathrm{ml}$ to $8 \mathrm{ml}$ per minute) did not appreciably alter these observations. When

TABLE I

Viruria in free-flow experiments after injection of Coxsackie B-1 virus into the right renal artery of dogs

\begin{tabular}{|c|c|c|c|c|c|c|c|}
\hline \multirow[b]{2}{*}{ Dog no. } & \multirow{2}{*}{$\begin{array}{c}\text { Vol of } \\
\text { inoculum }\end{array}$} & \multicolumn{3}{|c|}{$\log _{10}$ TCID $_{50}$ per $\mathrm{ml}^{*}$} & \multirow{2}{*}{$\begin{array}{l}\text { Urine } \\
\text { flow }\end{array}$} & \multicolumn{2}{|c|}{$\begin{array}{l}\text { Time of first } \\
\text { appearance }\end{array}$} \\
\hline & & Inoculum & Plasma & Urine & & Virus & Hippuran-181I \\
\hline & $m l$ & & & & $m l / \min$ & $\min$ & $\min$ \\
\hline 1 & 5 & 8.0 & 4.3 & $\begin{array}{l}\mathrm{R} 2.0 \\
\mathrm{~L} 2.0\end{array}$ & $\begin{array}{l}0.4 \\
0.5\end{array}$ & $\begin{array}{l}3 \\
3\end{array}$ & $\begin{array}{c}3 \\
\text { None }\end{array}$ \\
\hline 3 & 8 & 7.0 & 2.3 & $\begin{array}{ll}\text { R } 0.3 \\
\text { L } 0.3\end{array}$ & $\begin{array}{l}0.6 \\
0.8\end{array}$ & $\begin{array}{l}3 \\
3\end{array}$ & $\begin{array}{c}5 \\
\text { None }\end{array}$ \\
\hline 4 & 10 & 7.0 & 3.3 & $\begin{array}{ll}\mathrm{R} & 0.2 \\
\mathrm{~L} & 0.3\end{array}$ & $\begin{array}{l}0.7 \\
0.7\end{array}$ & $\begin{array}{l}5 \\
5\end{array}$ & $\begin{array}{c}10 \\
\text { None }\end{array}$ \\
\hline 17 & 10 & 4.0 & 1.5 & $\begin{array}{l}\text { R } 0 \\
\text { L } 0\end{array}$ & $\begin{array}{l}3.5 \\
4.0\end{array}$ & & $\begin{array}{c}3 \\
\text { None }\end{array}$ \\
\hline 19 & 10 & 8.0 & 4.3 & $\begin{array}{ll}R & 1.5 \\
L & 1.5\end{array}$ & $\begin{array}{l}1.0 \\
1.0\end{array}$ & $\begin{array}{l}2 \\
2\end{array}$ & $\begin{array}{l}6 \\
8\end{array}$ \\
\hline 22 & 8 & 7.0 & 3.0 & $\begin{array}{ll}\mathrm{R} & 0.5 \\
\mathrm{~L} & 1.0\end{array}$ & $\begin{array}{l}7.0 \\
8.0\end{array}$ & $\begin{array}{l}3 \\
3\end{array}$ & $\begin{array}{c}3 \\
\text { None }\end{array}$ \\
\hline
\end{tabular}

${ }^{*} \mathrm{TCID}_{50}=50 \%$ tissue culture infective dose. $\mathrm{R}$ and $\mathrm{L}=$ right and left kidneys. 


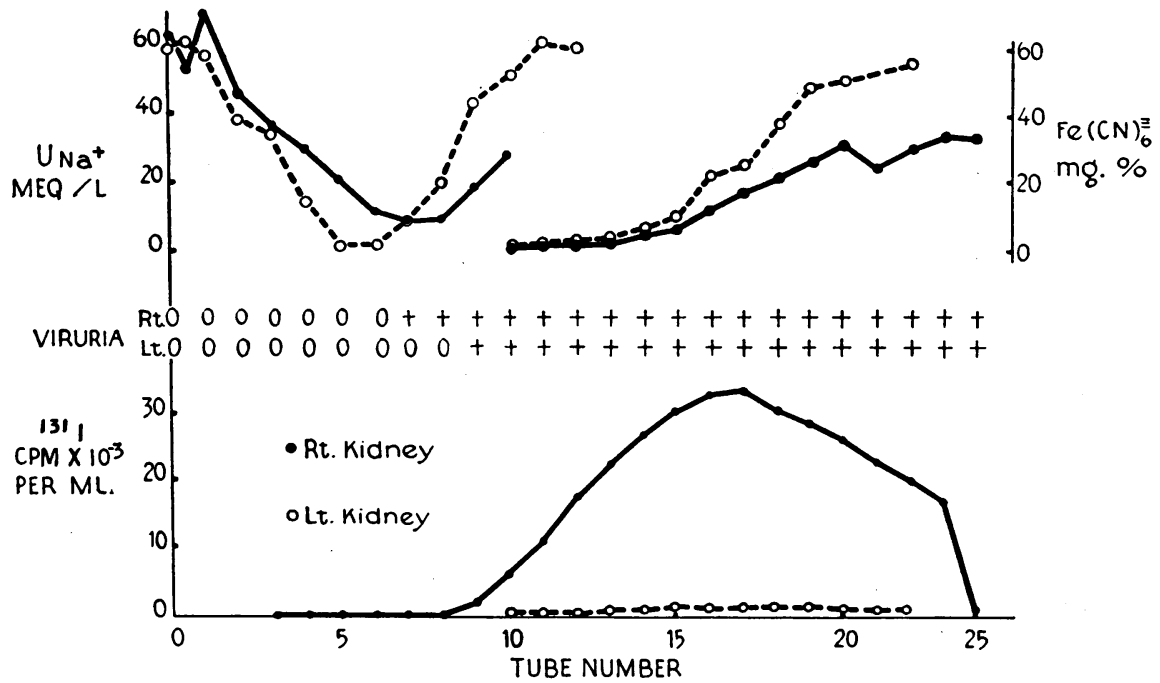

Fig. 2. A TYPICAL STOP-FLOW EXPERIMENT FOR THE STUdY OF COXSACKIE B-1 VIRURIA IN THE DOG. Viruria, sodium concentration as a measure of distal tubular function, Hippuran- ${ }^{181} \mathrm{I}$ concentration as a measure of proximal tubular activity, and ferrocyanide concentration as a marker of glomerular filtration are shown in urine samples from each kidney collected for 3 minutes after stopping urine flow.

viremia was not sufficiently high (dog 17$)$, viruria did not occur.

Stop-flow experiments. In an attempt to relate viruria to a functional locus in the nephron, "stopflow" experiments were carried out in dogs injected with sufficient virus to produce viruria. The results of the first stop-flow experiment are detailed in Figure 2. Virus was not detected in the first six tubes of either side. The seventh tube on the right and the ninth tube on the left contained virus. Thereafter, all specimens contained virus. A pool from tubes 25 to 31 contained $10^{1.5} \mathrm{TCID}_{50}$ per ml. Virus first appeared in the region associated with the dip in urinary sodium

TABLE II

Viruria in stop-flow experiments after injection of Coxsackie B-1 virus into the right renal artery of dogs

\begin{tabular}{|c|c|c|c|c|c|}
\hline \multirow[b]{2}{*}{ Dog no. } & \multicolumn{4}{|c|}{ Tube number corresponding to } & \multirow[b]{2}{*}{$\begin{array}{c}\text { Glomerular } \\
\text { urine† }\end{array}$} \\
\hline & & Sodium & $\begin{array}{c}\text { Virus } \\
\text { first } \\
\text { appearance }\end{array}$ & $\begin{array}{c}\text { Maximal } \\
\text { proximal } \\
\text { tubular } \\
\text { activity* }\end{array}$ & \\
\hline 10 & $\begin{array}{l}\mathrm{R} \\
\mathrm{L}\end{array}$ & $\begin{array}{l}5 \\
5\end{array}$ & $\begin{array}{l}7 \\
9\end{array}$ & $\begin{array}{l}9 \\
9\end{array}$ & $\begin{array}{l}20 \\
17\end{array}$ \\
\hline 11 & $\begin{array}{l}\mathbf{R} \\
\mathbf{L}\end{array}$ & $\begin{array}{l}\text { ND } \\
\text { ND }\end{array}$ & $\begin{array}{l}5 \\
6\end{array}$ & $\begin{array}{l}15 \\
15\end{array}$ & $\begin{array}{l}23 \\
20\end{array}$ \\
\hline 13 & $\mathrm{R} \S$ & 4 & 5 & 11 & 17 \\
\hline 15 & $\begin{array}{l}\mathbf{R} \\
\mathbf{L}\end{array}$ & $\begin{array}{l}6 \\
6\end{array}$ & $\begin{array}{l}7 \\
9\end{array}$ & $\begin{array}{l}11 \\
12\end{array}$ & $\begin{array}{l}\text { ND } \\
\text { ND }\end{array}$ \\
\hline 20 & $\mathbf{L} \|$ & 6 & 4 & 15 & ND \\
\hline 21 & $\begin{array}{l}\mathrm{R} \\
\mathrm{L}\end{array}$ & $\begin{array}{l}7 \\
5\end{array}$ & $\begin{array}{l}7 \\
5\end{array}$ & $\begin{array}{l}12 \\
13\end{array}$ & $\begin{array}{l}16 \\
16\end{array}$ \\
\hline $\begin{array}{l}\text { No. observations } \\
\text { Mean } \\
\text { Range }\end{array}$ & & $\begin{array}{l}8 \\
5.5 \\
4-7\end{array}$ & $\begin{array}{l}10 \\
6.3 \\
4-9\end{array}$ & $\begin{array}{l}10 \\
12.2 \\
9-15\end{array}$ & $\begin{array}{c}7 \\
18.4 \\
16-23\end{array}$ \\
\hline
\end{tabular}

* The maximal slope of the curve of ${ }^{131}$ I activity.

$\dagger$ The maximal slope of the curve of ferrocyanide concentration.

$\ddagger \mathrm{ND}=$ not done.

Only right side available.

\| Only left side available. 
concentration, attributed by Malvin, Wilde, and Sullivan to distal tubular function (6). Maximal proximal tubular activity, as marked by rapidly increasing Hippuran- ${ }^{131}$ I excretion, and glomerular function indicated by the appearance of ferrocyanide, occurred in specimens collected well after viruria had commenced.

The results of six experiments in which stopflow analysis was used to study viruria are summarized in Table II. In each experiment, viruria was detected within the first nine tubes, at or before the maximal slope of urinary ${ }^{131}{ }^{1}$ concentration and before the detection of ferrocyanide. Experiment 11 was unique, since the dose of virus injected, $10^{8.5} \mathrm{TCID}_{50}$ per ml, resulted in significant viruria on the injected side only. Tube 6 was the only one positive for virus on the left (uninjected) side; tubes 5 to 22 all contained virus on the right. The last six tubes on the right were again negative, suggesting that the small amount of virus excreted by the kidney had been cleared very promptly from the tubular lumina. Blood levels of $10^{3.5} \mathrm{TCID}_{50}$ per $\mathrm{ml}$ were noted at 5 and 10 minutes after virus injection in this experiment. In two other experiments minimal or no viruria at all was noted in late specimens on one or both sides. Viruria was never detected in the first four stop-flow urine collections, suggesting that virus transfer from bleeding into the ureters or pelves of the kidney could not account for the observed viruria. When urine/plasma ratios of virus were determined from urine collected after the stop-flow specimens, they were always of the order of magnitude of $10^{-3}$. This fact plus the virtual absence of microscopic hematuria in the same specimens suggest strongly that the viruria seen in stop-flow experiments cannot be accounted for by bleeding into tubular lumina. These experiments also indicate the rapidity with which virus may enter dog urine from blood, since the first specimens containing virus were collected less than 2.5 minutes after starting the injection.

Routine histologic studies of sections from kidneys obtained within 1 hour of completion of these experiments usually revealed minimal edema and slight round cell infiltration. Similar findings were noted in dogs used for renal physiological studies without the injection of virus. Occasionally, gross examination of the kidneys revealed a macroscopic parenchymal scar. In none of these instances did microscopic examination show diffuse renal disease.

\section{Discussion}

Coxsackie B-1 virus is well suited to studies of viruria, since it is stable and easily detected in biological fluids. Being approximately $30 \mathrm{~m} \mu$ in diameter and roughly spherical in shape (16), it is representative of a large group of mammalian RNA enteroviruses, now called picornaviruses (17). In addition, it is considerably larger than many of the macromolecules that have been studied in the urine of man and animals $(18,19)$. This agent was also isolated from the urine of infected suckling mice in studies by Pappenheimer, Kunz, and Richardson in 1951 (20). We used Coxsackie B-1 virus to determine whether macromolecules of the size of virus particles can pass from the circulating blood into the urine. In dogs, a dose of Coxsackie B-1 virus resulting in sustained viremia of more than $10^{2} \operatorname{TCID}_{50}$ per $\mathrm{ml}$ resulted in viruria. This occurred within minutes after direct renal arterial injection, but occurred bilaterally in most experiments, suggesting that transient very high blood levels on the injected side did not result in augmented virus excretion. Evidently sustained exposure to high levels of circulating virus was necessary for viruria.

Stop-flow studies indicated that in most nephrons the virus entered urine in or just after the area corresponding to the dip in sodium concentration usually attributed to distal tubular function. This is consistent with the data first obtained in free-flow experiments in which virus always appeared in ureteral urine before or coincident with the detection of Hippuran-131I or phenol red. Schultz and Neva (3) recovered poliovirus from the bladder urine of a rat in which both ureters had been ligated before the intravenous injection of virus. From this experiment, it was considered that permeability to virus might be demonstrable in other parts of the collecting system of the genitourinary tract. This was not the case in our studies of Coxsackie B-1 viruria in dogs, however, since virus was found in the urine at the tubular level, but not from specimens in contact with the pelvis or short segment of ureter above the catheters. Unfortunately, our experimental design did not exclude passage of virus through parts of the nephron above the distal segment. 
In three stop-flow experiments, however, virus was detected in specimens stopped in tubular areas, but not in those that were contained in the glomeruli during stop flow. This suggests that the tubular areas are more likely to allow passage of virus particles, but does not eliminate some passage across the glomerulus when viremia is intense.

How accurately do these data reflect physiological events and not experimental artifacts? The problem of direct blood contamination in collection of specimens was considered. We selected only the experiments in which rare erythrocytes (or none at all) were present in centrifuged specimens of urine collected before or after the experimental procedure. Since red cells were present in much higher concentrations in the plasma than virus particles, we felt that this was a sufficient precaution to eliminate "bleeding" (as we normally think of it) as a cause of viruria in our experiments. There are also other aspects of the study that are not readily controlled, such as anesthesia, stress of surgery, and diuresis, which may have affected the occurrence of viruria. The extent to which the quantitative data can be applied to the unanesthetized, intact animal remains to be determined. Passage of virus into urine was not shown to affect the physiological function studies of the nephron, nor were morphological changes attributable to viruria seen in routine histological studies.

Viruria occurs in virus infections of dogs with canine hepatitis (21) and distemper viruses (22). Distemper antigens have been detected in bladder mucosa by fluorescent antibody techniques, suggesting this as a site for viral entry into urine (22). However, bladder epithelial cells might initially have become infected by urine descending from the upper urinary tract with virus transferred from the blood when critical levels of viremia were exceeded.

Studies of virus excretion after intravenous injection reported by Russian workers have revealed a difference of opinion on the significance of viruria in ridding the host of the infection (23). The current view, supported by the data of Petrov (5) and Keller and Zatzman (4), minimizes the effectiveness of viruria in defense against infection, but recognizes its occurrence in the presence of sufficiently high blood levels of virus without invoking direct viral multiplication in the genitourinary tract. Thus, excretion rates of $B$. megatherium phage were shown to increase with plasma levels above $10^{4}$ particles per $\mathrm{ml}$ by Keller and Zatzman (4).

Finally, these studies bear on the question of the origin of other macromolecules found in urine. Sites of viral permeation presumably could be available to other molecules of smaller or equal size. Because viruses are capable of quantitation in very minute amounts (sensitive detection methods permit fewer than 10 infective particles to be identified in some systems), it would be expected that the processes governing their excretion could be more precisely identified. Studies with inert particles have been reported that also indicate renal permeability to large particles. Farquhar, Wissig, and Palade, in studies using the electron microscope (24), showed the passage through the intact glomerulus of very few of many ferritin particles circulating in rat blood, but tubular passage was not studied. Ferritin is approximately $100 \mathrm{~A}$ in diameter, which would place it below the size of the smallest known viruses. Grotte (25) has postulated capillary "leaks" in the kidney through which large molecules may pass in "bulk flow," as estimated from his studies using dextran particles varying in molecular weight from 50,000 to 300,000 . Swann, Ormsby, Delashaw, and Tharp have made similar suggestions (26). Such studies do not detract from the general concept that the kidney is a selective and efficient filter. They do indicate, however, that the retention of certain particles is not perfect. These imperfections may have biological significance related to the nature of the particle and to certain disease processes. Certainly our studies suggest that further detailed microscopic examination of the proximal and distal tubular regions is indicated to explore the morphologic basis for their permeability to large molecules such as Coxsackie B-1 virus.

\section{Summary}

Injection of Coxsackie B-1 virus into the right renal artery of anesthetized dogs resulted in virus detection in the urine if viremia greater than $10^{2}$ $50 \%$ tissue culture infective dose per $\mathrm{ml}$ was sustained. Virus appeared in ureteral urine from both kidneys, despite unilateral injections, as early as 30 seconds after virus infusion for approximately 
1 minute. In experiments with free flow of urine, virus was always detected before or coincident with the appearance of simultaneously injected Hippuran-131I or phenol red. In stop-flow studies, virus was first detected in specimens from the distal tubular area (or just proximal to it) as determined from sodium concentrations, but continued to appear in specimens from more proximal areas of the nephron. In three experiments virus was present in tubular urine but absent in glomerular urine marked by the excretion of ferrocyanide. We conclude that facilitated excretion of Coxsackie B-1 virus into urine in the area of the distal tubule occurred under the conditions of these experiments.

\section{Acknowledgments}

The authors are grateful to Dr. David P. Earle for his advice and stimulating criticism. The technical assistance of Carolyn Katkus, Mona Sakura, Povilas Pranckevicius, and Sherwin Lewis is gratefully acknowledged.

\section{References}

1. Weller, T. H., and J. B. Hanshaw. Virologic and clinical observations on cytomegalic inclusion disease. N. Engl. J. Med. 1962, 266, 1233.

2. Gresser, I., and S. L. Katz. Isolation of measles virus from urine. N. Engl. J. Med. 1960, 263, 452.

3. Schultz, I., and F. A. Neva. Relationship between blood clearance and viruria after intravenous injection of mice and rats with bateriophage and polioviruses. To be published.

4. Keller, R., and M. L. Zatzman. Studies on the factors concerned in the disappearance of bateriophage particles from the animal body. J. Immunol. 1959, 83, 167.

5. Petrov, V. K. Excretion of phage through the kidney of white mice and dogs in Problems of the Pathogenesis and Immunology of Virus Infections. Leningrad, 1955, p. 143.

6. Malvin, R. L., W. S. Wilde, and L. P. Sullivan. Localization of nephron transport by stop flow analysis. Amer. J. Physiol. 1958, 194, 135.

7. Pullman, T. N., A. R. Lavender, I. Aho, and H. Rasmussen. Direct renal action of a purified parathyroid extract. Endocrinology 1960, 67, 570.

8. Pitts, R. F., R. S. Gurd, R. H. Kessler, and K. Hierholzer. Localization of acidification of urine, potassium and ammonia secretion and phosphate reabsorption in the nephron of the dog. Amer. J. Physiol. 1958, 194, 125.

9. Pizzi, M. Sampling variation of the fifty per cent end-point, determined by the Reed-Muench (Behrens) method. Hum. Biol. 1949, 22, 151.
10. Holland, J. J., and L. C. McLaren. Improved method for staining cell monolayers for virus plaque counts. J. Bact. 1959, 78, 596.

11. Smith, H. W. Principles of Renal Physiology. New York, Oxford University Press, 1956, p. 213.

12. Kingsley, G. R., and R. R. Schaffert. Micro flame photometric determination of sodium, potassium, and calcium in serum with organic solvents. J. biol. Chem. 1954, 206, 807.

13. Van Slyke, D. D., A Hiller, and B. F. Miller. The clearance, extraction percentage and estimated filtration of sodium ferrocyanide in the mammalian kidney. Comparison with inulin, creatinine and urea. Amer. J. Physiol. 1935, 113, 611.

14. Tauxe, W. N. The radioisotope renogram in renal artery disease. Proc. Mayo Clin. 1961, 36, 684.

15. Mims, C. A. Aspects of the pathogenesis of virus diseases. Bact. Rev. 1964, 28, 30.

16. Morgan, C., C. Howe, and H. M. Rose. Intracellular crystals of Coxsackie virus viewed in the electron microscope. Virology 1959, 9, 145.

17. Virus Subcommittee of the International Nomenclature Committee. Recommendations on virus nomenclature. Virology 1963, 21, 516.

18. Putnam, F. W. Alterations of protein metabolism in multiple myeloma. Interrelationship of abnormal serum globulins and Bence Jones proteins. Physiol. Rev. 1957, 37, 512.

19. Shuster, S., J. H. Jones, and G. Flynn. Renal tubular secretion of human plasma proteins and Bence Jones protein. Brit. J. exp. Path. 1963, 44, 145.

20. Pappenheimer, A. M., L. J. Kunz, and S. Richardson. Excretion of Coxsackie virus (Conn. no. 5 strain) in the urine of infected mice. Proc. Soc. exp. Biol. (N. Y.) 1951, 77, 405.

21. Poppensiek, G. C., and J. A. Baker. Persistence of virus in urine as factor in spread of infectious hepatitis in dogs. Proc. Soc. exp. Biol. (N. Y.) 1951, 77, 279.

22. Coffin, D. L., and C. Liu. Studies on canine distemper infection by means of fluorescein-labeled antibody. II. The pathology and diagnoses of the naturally occurring disease in dogs and the antigenic nature of the inclusion body. Virology 1957, 3, 132.

23. Smorodintsev, A. A. A critical examination of the views of $\mathrm{L}$. A. Zilber on the protective role of the processes of excretion of viruses through the kidneys. Problems of Virology 1951, 2, 53.

24. Farquhar, M. G., S. L. Wissig, and G. E. Palade. Glomerular permeability I. Ferritin transfer across the normal glomerular capillary wall. J. exp. Med. 1961, 113, 47.

25. Grotte, G. Passage of dextran molecules across the blood-lymph barrier. Acta chir. scand. 1956 (suppl. 211), 65.

26. Swann, H. G., A. A. Ormsby, J. B. Delashaw, and W. W. Tharp. Relation of lymph to distending fluids of the kidney. Proc. Soc. exp. Biol. (N. Y.) 1958, 97, 517. 